\title{
Identification of Target Proteins of Glycosyltransferases Using Functional Glycomics by Gene Expression Regulation
}

\author{
糖転移酵素の発現制御とターゲット糖タンパク質の同定
}

\author{
Kondo, Akihiro \\ Department of Glycotherapeutics, Osaka University Graduate School of Medicine, Osaka 565-0871, Japan \\ FAX: 81- 6879-3646; E-mail: kondoa@glycot.med.osaka-u.ac.jp
}

Key Words: core fucosylation, functional glycomics, knockout, knockdown, lectin

\begin{abstract}
Comprehensive analyses of proteins from cells and tissues are the most effective means of elucidating the expression patterns of individual disease-related proteins. On the other hand, the simultaneous separation and characterization of proteins by electrophoresis followed by MS analysis is one of the fundamental approaches to proteomic analysis. However, these analyses do not permit the complete structural identification of glycans in glycoproteins or their structural characterization. Over half of all known proteins are glycosylated and glycan analyses of glycoproteins are requisite for fundamental proteomics studies. The analysis of glycan structural alterations in glycoproteins is becoming increasingly important in terms of biomarkers, quality control of glycoprotein drugs, and the development of new drugs. However, the usual glycomics approach which characterizes and/or identifies glycans, provides some structural information, but it does not provide any information on the functionality of glycans. Therefore, in order to elucidate the function of glycans, functional glycomics which identifies the target glycoproteins of glycosyltransferases and characterizes functional roles of glycans represents a promising approach. In this review, we show examples of a functional glycomics technique using $\alpha 1,6$ fucosyltransferase gene (Fut8) in order to identify the target glycoproteins.
\end{abstract}

\section{A. Introduction}

The glycosylation of $\mathrm{N}$-glycans represents a critically important post-translational modification reaction, and the comprehensive functional analysis of proteins is a target for the next stage of proteomic research. It is common knowledge that over $50 \%$ of all in mammalian serum proteins and about $80 \%$ of cell membrane proteins are glycosylated and that glycans play crucial roles in various biological events including cell recognition (1), adhesion (2) and cell-cell interaction (3). Glycans of glycoproteins, which are displayed
要 約

細胞や組織からのタンパク質の総合的解析は、個々の疾患 関連タンパク質の発現パターンの研究において最も有効な手 段である。一方、タンパク質の網羅的分離掞よび同定において、 電気泳動の後、質量分析を行う解析方法は、プロテオミクス 分析の基本的な方法のひとつである。しかしながら、これら の方法は、必ずしも糖タンパク質糖鎖の同定や構造決定が完 全にできるわけではない。現在知られているタンパク質の半 数以上は糖夕ンパク質であるため、基本的なタンパク質解析 研究に扔いてその糖鎖解析が要求されるわけである。糖タン パク質の糖鎖構造解析は、バイオマーカー探索、糖タンパク 医薬品の品質管理、新薬開発などの分野に抏いてその重要性 を増してきている。しかしながら、現在行われているような 単なる糖鎖構造を解析するだけの ‘グライコミクス’ 研究で は、充分な糖鎖機能解析が行われているとは言い難い。よって、 糖鎖機能解析を行うためには、解明しようとしている役割を 担う機能分子としての糖鎖構造の解析が必要である。

本総説では、 $\alpha 1,6$ フコース転移酵素 (Fut8) を例に、機能分 子としての糖鎖機能解析を紹介する。

\section{A. はじめに}

糖タンパク質の $N$ - 結合型糖鎖付加はタンパク質の翻訳 後修飾反応の中でも非常に重要なものであり、糖鎖を含めた タンパク質の網羅的機能解析はプロテオミクス研究の次のス テップの課題とも言えるものである。哺乳動物の血清タンパ ク質の半分以上、膜タンパク質に至ってはその 8 割以上が糖 鎖修飾を受けていることが知られている。そしてその糖鎖が、 細胞間認識 (1)、細胞接着 (2)、細胞間相互作用 (3) など様々な 
on cell surface membranes, are structurally changed during carcinogenesis and development (4). Functional glycomics is an important strategy for the elucidation of the functions of glycans and this new field promises to provide fundamental answers in the area of functional proteomic research $(5,6)$. To ascertain the functional relationship between a protein and its glycosylation status, we knockout and knockdown a specific glycosyltransferase gene and characterize the altered products according to the lack of a specific residue. These structural changes may occur as the result of alterations in the expression levels of glycosyltransferases, which are implicated in the biosynthesis and trimming of the glycoforms. Structural analysis of glycans of the whole cell lysate in which glycoproteins are modified by glycosyltransferase gene knockout or knockdown is carried out, the glycan structures are compared with those of wild-type cells: this is referred to as a glycomic analysis.

Glyco-proteomic analysis requires that a sample be purified prior to the glycan structural analysis. When we want to analyze a specific glycan containing a glycoprotein of interest, the cell lysate can be purified or enriched by affinity chromatography using lectin(s) or sugar specific ligands. Then the glycoproteins are analyzed and identified comprehensively. This is "glyco-proteomic" analysis. Glycoproteomic analysis is useful for identification of target glycoproteins of glycosyltransferase. On the other hand, affinity columns which specifically recognize proteins such as antibody, specific binding proteins or specific ligands, are useful for purification or enrichment of the glycoproteins of interest from a cell lysate and the glycan structures of the binding fraction can be analyzed. This strategy is referred to as a "proteo-glycomic" analysis and is useful for certain types of clinical glycomics, because information can be obtained on glycan structural alterations in the particular protein. Finally the characterization of functional glycans of glycoproteins lacking the components of glycans is analyzed by various cellular and molecular approaches. This is referred to as functional glycomics. Actually functional glycomics are carried out through the combination of glyco-proteomics and proteo-glycomics.

This review will focus on our strategy for functional glycomics using Fut8 knockout mice and knockdown cells to elucidate the function of core fucose ( $\alpha 1,6$ fucose) in $\mathrm{N}$-glycan structure. Fut8 has been purified from four different sources, in order to better understand its biological function in biological phenomena (7-10). Voynow et al. first partially purified and characterized Fut8 from cultured human skin fibroblasts of cystic fibrosis subjects in 1991 (7). The purification efficacy was dramatically increased via the use of substrate affinity chromatography. In 1996, Uozumi et al. succeeded in the purification and cDNA cloning of Fut8
生物学的反応に重要な役目を果たしていることが報告されて いる。細胞表面に存在する糖タンパク質の糖鎖は、細胞の癌 化や癌の進行によってその構造が変化することが知られてい る(4)。機能グライコミクスは糖鎖の機能を明らかにする重要 な研究方法であり、この新たな分野は機能プロテオミクス研 究分野に扮いて基本的な情報を与えるものである(5、6)。糖転 移酵素遺伝子をノックアウトやノックダウンしてその発現量 を抑制し、特定の残基を欠失させて得られる構造変化した糖 タンパク質の機能を解析することによって、糖タンパク質糖 鎖の重要性を確かめることができる。これらの構造変化はグ ライコフォームの生合成やトリミングに関与する糖転移酵素 の発現レベルが変化することによって起こるものと考えられ る。糖転移酵素遺伝子をノックアウトやノックダウンさせ糖 転移酵素の発現を抑制した細胞と未処理の細胞の全糖鎖の構 造を網羅的に比較することをグライコミクス解析と言う。

一方、ある糖タンパク質の糖鎖構造に注目し、レクチン や糖鎖特異的なリガンドなどを用いて細胞溶解液からその構 造を持つ糖タンパク質を選別し、それがどのようなタンパク 質であるかを網羅的に解析する手法を「グライコプロテオミ クス」解析と称する。グライコプロテオミクスは糖転移酵素 のターゲット糖タンパク質の同定に有効な方法である。また、 ある糖タンパク質のタンパク質部分に注目しその特定の糖夕 ンパク質に対するアフィニティカラムを用いて細胞溶解液か ら特定の糖タンパク質を精製し、その後、その特定の糖タン パク質の糖鎖どうしを比較する手法を「プロテオグライコミ クス」解析と称する。この方法は特定のタンパク質における 糖の構造変化に関する情報が得られるため、ある種の臨床グ ライコミクスとして有効である。糖の構成成分を欠失させた 糖タンパク質の機能性糖鎖の分析が細胞あるいは分子からの 様々なアプローチによって解析されており、機能グライコミ クスと呼ばれている。実際の糖鎖の機能解析研究では、これ らの手法を駆使して実験を行うものである。

この総説は、糖鎖の機能解析研究において Fut8 のノック アウトマウスやノックダウン細胞を使って $N$ - 結合糖鎖の $a 1,6$ コアフコースの機能を明らかにしてきた我々の研究方法に焦 点を当てて紹介する。Fut8 は、これまでに 4 種類の異なった 酵素源からそれらの中に抢ける生物学的機能を理解するため に精製されてきた (7-10)。Voynow らは、1991 年に襄胞性緎 維症の患者の皮膚由来の繊維芽細胞から Fut8 を精製し特性を 調べた (7)。精製の際に、基質親和性クロマト法を使い飛躍的 に純度の高い酵素の精製に成功している。1996 年には、Uozumi らがブタ脳から Fut8 の精製に成功し、cDNA クローニン 
from porcine brain (8). Although no sequence homology was found in the Fut 8 cDNA, compared with other members of the fucosyltransferase family, Fut 8 cDNA contains nine conserved amino acid sequences, which are completely consistent with mammalian $\mathrm{H} / \mathrm{Se}$ type fucosyltransferase (11). Fut8 appears to be a type II transmembrane protein, similar to other glycosyltransferases. The expression of Fut 8 mRNA has been detected as a single $3.5 \mathrm{~kb}$ band in a variety of rat tissues with the exception of liver and pancreas (12). Yanagidani et $a l$. succeeded in the purification and cDNA cloning of FUT8 from a human gastric cancer cell line, MKN45 (9).

\section{B. Glyco-Proteomic Analysis}

A comparative method for the analysis of glycans released from serum glycoproteins and for the recovery and identification of proteins with aberrant glycosylation, as a function of cancer diagnosis, is a method of glyco-proteomic analysis. Lectins are very useful tools for the separation of glycoproteins in sample mixtures. In the case of Fut8 knockout mice or transgenic mice or knockdown cells, several fucose specific lectins are available for these purposes (Table I). There are some recognition specificities. UEA-I and AAnA recognize H-determinants (Fuc $\alpha 1,2-G a l$ ). LTA, AAL, AOL and RSL recognize Fuc $\alpha 1,2-$ Gal, Fuc $\alpha 1$, 3-GlcNAc, Fuc $\alpha 1,4-G l c N A c$, and Fuc $\alpha 1,6-G l c N A c$. Moreover, AAL, AOL and RSL bind to core-Fuc of $N$-glycans (Fuc $\alpha 1,6$-GlcNAc) with high affinity. The detection of fucose in glycoproteins involves the use of Lens culinaris agglutinin (LCA), which recognizes core-fucosylated bianntenary $\mathrm{N}$-glycans (13).

Block et al. reported on a comparative method for the analysis of $\mathrm{N}$-glycans released from serum glycoproteins
グにも成功した (8)。その報告によると Fut8 の塩基配列は、そ れまで見つかっていた他のフコース転移酵素との相同性が無 かったが、哺乳類の H/Se 型のフコース転移酵素に保存された 9アミノ酸と一致する配列を持っていたということである(11)。 Fut8 は、他の糖転移酵素と同じようにI I 型膜貫通タンパク

質であった。また、Fut8の発現を種々のラットの臓器で調べ たところ、肝臟とすい臟以外で $3.5 \mathrm{~kb}$ のバンドとして検出され た (12)。Yanagidani らは、ヒトの胃がん細胞株である MKN45 から FUT8 の精製扔よび $c D N A$ クローニングに成功している (9)。

\section{B. グライコプロテオミック分析}

癌の診断法の研究の際などに、正常な血清中の糖鎖と、が ん患者の血清中から検出される異常糖タンパク質の糖鎖を比 較することをグライコプロテオミック分析という。レクチン は、試料混合物の中から目的の糖タンパク質を分離する際に 非常に有用である。Fut8 のノックアウトマウス、トランスジェ ニックマウス、ノックダウン細胞を研究する際、表 1 にある ような様々なフコース結合レクチンを使うことが出来る。( 表 -1)これらのレクチンにはそれぞれ認識する構造に特性があ る。UEA-I と AAnA は、H抗原と呼ばれる Fuc $\alpha 1,2-G a l$ 構造

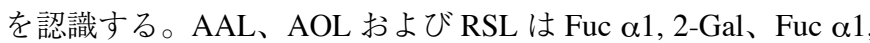
3-GlcNAc、Fuc $\alpha 1$, 4-GlcNAc および Fuc $\alpha 1$, 6-GlcNAc のフコー スを認識する。その中でも AAL、AOL およびRSLは、糖夕 ンパク質の $N$-結合型のコアフコース (Fuc a1, 6-GlcNAc) に高 い親和性を示す。糖タンパク質のフコースを認識するときに よく用いられている Lens culinaris agglutinin (LCA) は、 $N$-結 合複合型糖鎖のうちコアフコースの結合した 2 本鎖糖鎖を強 く認識する (13)。

Block らが、フコースに親和性のある Lens culinaris agglutinin (LCA)、Pisum sativum agglutinin (PSA) および Vicia faba

Table I. Fucose Specific Lectins

Linkage Specificity Lectin

Fuc $\alpha 1,2-\mathrm{Gal}$

Fuc $\alpha 1,3-$ GlcNAc

Fuc $\alpha 1,4-$ GlcNAc
LTA, AAL, AOL, RSL

UEA-I, AAnA, LTA, AAL, AOL, RSL

LTA, AAL, AOL, RSL

Fuc $\alpha 1,6-$ GlcNAc AAL, AOL, RSL

UEA-I (Ulex europaeus agglutinin), AAnA (Anguilla anguilla agglutinin), LTA (Lotus tetragonolobus agglutinin),

AAL (Aleuria aurantia lectin), AOL (Aspergillus oryzae lectin), RSL (Rhizopus stolonifer lectin) 
and for the recovery and identification of proteins by fucose recognizing lectins from Lens culinaris agglutinin (LCA), Pisum sativum agglutinin (PSA), and Vicia faba agglutinin (VFA) with aberrant glycosylation, for purposes of cancer diagnosis (14). They showed that woodchucks diagnosed with hepatocellular carcinomas (HCC) have dramatically higher levels of serum-associated core-fucose, compared to woodchucks that are diagnosed without HCC. The coupling of the lectins (LCA, PSA, and VFA) selection method with 2-DE gel proteomics has permitted the identification of several glycoproteins with altered glycosylation patterns as a function of cancer. Golgi Protein 73 (GP73) was found to be elevated and hyper-fucosylated in animals with HCC.

\section{Proteo-Glycomic Analysis}

In the case of proteo-glycomic analysis, one could purify the glycoproteins using specific ligands for proteins such as antibodies, enzyme substrates, inhibitors, binding proteins etc.

Conventional glycan structural analyses are classified in this category and one of the aims of clinical glycomics is finding glycans with altered behavior in disease (with regard to structure, function, interaction or expression), thus forming a starting point for improvements in clinical care for that disease. One of the goals of glycomic technologies is to find disease specific changed glycans, study their structure, function and interactions of a specific glycan or types of glycans, which are derived from disease-associated glycoproteins (e.g. triantennary sugar chains). It is well known that malignant transformation is associated with abnormal glycosylation, resulting in the expression of altered glycan biomarkers. The monoclonal antibodies against tumor marker glycoproteins were widely used for clinical diagnosis and so-called cancerassociated antigens have been studied for over two decades. $\alpha$-Fetoprotein (AFP) glycans increased fucosylation of glycans occur in certain types of diseases (15). AFP is a glycoprotein produced in the mammalian embryonic liver and is a major serum protein in the developing fetus. AFP is a serum protein, the reappearance of which in mice with hepatomas has been demonstrated $(16,17)$, as well as in patients with hepatocellular carcinomas (HCC) and in rat serum treated with carcinogens (18).

\section{Fut8 and TGF $\beta$-1 Signaling(19)}

To investigate the physiological functions of the core fucose, we generated $F u t 8$ knockout mice and found that the disruption of Fut8 induces severe growth retardation and death during postnatal development (19). A histopathological analysis revealed that Fut 8 knockout mice showed emphysema-like changes in the lung, verified by a physiological compliance analysis. Biochemical studies indicate that lungs from agglutinin (VFA) を用いて、血清糖タンパク質から遊離され る $N$ - 結合糖鎖の分析や血清中のフコース結合糖タンパク質 の精製を行い、癌の診断の研究を行っている(14)。彼らは肝細 胞癌のウッドチャックの糖鎖を解析し、癌発症の際にコアフ コースが劇的に増加することを報告している。前述のフコー ス結合レクチン (LCA、PSA、VFA)を用いて精製してきた糖 タンパク質を 2 次元電気泳動で分離し、数種の糖タンパク質 の糖鎖が癌化に打いて変化することを報告している。中でも、 ゴルジタンパク質 73(GP73) が肝細胞癌のウッドチャックにお いて発現が立進し hyper-fucosylation が起こっていることを発 見している。

\section{C. プロテオグライコミック分析}

プロテオグライコミック分析の場合には、抗体や酵素基 質、阻害物質、結合タンパク質などの標的糖タンパク質に特 異的に結合する物質を用いて精製する方法を用いる。

従来の糖鎖構造解析はこのカテゴリーに分類され、疾患 特異的に変化する糖鎖 (構造、機能、相互作用、発現) を特定 するための臨床グライコミクスの目的のひとつであり、疾患 に対する臨床ケアの発展のために重要な研究分野である。グ ライコミクス技術のゴールの一つは、糖鎖構造やその機能、 特異的な糖鎖や特定の構造に相互作用するような糖鎖の研究 や、疾患特異的に変化する糖鎖の発見である。癌などの悪性 変化と糖鎖構造の変化が関係していることは良く知られてい るが、いくつかの応用例では、この糖鎖構造変化がバイオマー カーとなっている。糖タンパク質腫瘍マーカーに対するモノ クローン抗体は臨床診断に広く使われており、このテーマで の癌関連抗原の研究はここ 20 年以上続けられている。 $a$-フェ トプロテイン (AFP) の糖鎖のフコース結合量はある種の疾患 で上昇することが知られている(15)。AFPは哺乳類の胎児の 肝臟で作られる糖タンパク質で胎児の血清中の主要なタンパ ク質の一つである。AFP は肝がんマウスでその発現立進が報 告され (16、17)、同様の現象はヒトの肝細胞癌、発がん物質処 理したラットでも報告されている(18)。

\section{Fut8 と TGF $\beta$-1 シグナリング (19)}

コアフコースの生理学的機能を調べるために、我々は Fut8ノックアウトマウスを作成した。そのマウスは、Fut8の 発現が無いために非常に重篤な発育遅延を発生したり、出生 後程なく死んでしまうという様子が観察された (19)。病理組 織学的な解析によりFut8ノックアウトマウスの肺は、肺気腫 様の障害を起こしていることが観察されたが、これは肺の生 理的伸展性分析においても検証された。Fut8ノックアウトマ 
Fut8 knockout mice exhibit a marked overexpression of matrix metalloproteinases (MMPs), highly associated with lung-destructive phenotypes, and the down-regulation of extracellular matrix (ECM) proteins such as elastin, as well as retarded alveolar epithelia cell differentiation. These changes are consistent with a deficiency in TGF $\beta-1$ signaling, a pleiotropic factor that controls ECM homeostasis by down-regulating MMP expression and inducing ECM protein components. In fact, Fut 8 knockout mice have a marked dysregulation of TGF $\beta-1$ receptor activation and signaling, as assessed by TGF $\beta-1$ binding assays and a Smad 2 phosphorylation analysis (19).

\section{E. Fut8 and EGFR-Trypsin-PAR-2 Pathway (20)}

To investigate the underlying molecular mechanism by which growth retardation occurs, we examined the mRNA expression levels of $\mathrm{FutS}^{-/}$embryos (18.5 days postcoitum) using a cDNA microarray. The DNA microarray and realtime PCR analysis showed that a group of genes, including trypsinogens $4,7,8,11,16$ and 20 were down-regulated in $\mathrm{Fut}^{-/}$embryos. Consistently, the expression of trypsinogen proteins was found to be lower in $F u t 8^{-/ 2}$ mice in the duodenum, small intestine and pancreas. Trypsin, an active form of trypsinogen, regulates cell growth through a G-protein coupled receptor, the proteinase-activated receptor 2 (PAR-2). In a cell culture system, a Fut 8 knockdown mouse pancreatic acinar cell carcinoma, TGP49-Fut8-KDs, showed decreased, growth rate similar to that seen in $\mathrm{Fut}^{-/-}$mice, and the decreased growth rate was rescued by the application of the PAR-2 activating peptide (SLIGRL-NH ${ }_{2}$ ) (Fig. 1).
ウスの肺を生化学的に検証したところ、肺障害の現れている 部位でのマトリックスメタロプロテアーゼ (MMP) の発現立進 が観察され、同時にエラスチンなどの細胞外マトリックスタ ンパク質 $(\mathrm{ECM})$ 発現抑制や肺胞上皮細胞の分化遅延も観察さ れた。MMPの発現抑制によって誘導され、種々の因子によっ てその恒常性が保たれている ECMに扔けるこれらの変化は、 TGF $\beta$-1 シグナリングの低下によって引き起こされたといえ る。実際のところ、Fut8ノックアウトマウスは、TGF $\beta$-1 受 容体の活性化やシグナリングの著しい調節異常を示しており、 そのことは、TGF $\beta$-1 の結合分析や Smad2 のリン酸化分析 によって確かめられている (19)。

\section{E. Fut8 と EGFR-trypsin-PAR-2 経路 (20)}

我々は、先の項で述べたような Fut8ノックアウトマウス の発育遅延を発生する分子機構を詳しく調べるために、出生 前 ( 妊娠 18.5 日) の胎児の mRNA 発現を cDNA マイクロアレ イを用いて解析した。DNA マイクロアレイとリアルタイム $P C R$ 解析によって、Fut8ノックアウトマウスの胎児のトリプ シノーゲン 4、7、8、11、16、20 が野生型のマウス胎児に比 して発現抑制されていることが分かった。さらに、十二指腸、 小腸、すい臓に拐けるトリプシノーゲンタンパク質の発現も 抑制されていることが分かった。トリプシノーゲンの活性体 であるトリプシンは、G タンパク質共役受容体のひとつであ る proteinase-activated receptor 2(PAR-2) を介して細胞増殖を 制御できることが知られている。このことを確かめるために、 培養細胞を使ってFut8をノックダウンしたマウス膵がん細胞 (TGP49-Fut8-KD) を作成した。その細胞は、Fut8 ノックアウ トマウスの発育遅延と同様ともとれる細胞増殖能の低下がみ られたが、その低下した細胞増殖能は、PAR-2 活性化ペプチ ド (SLIGRL-NH $H_{2}$ )の添加で回復した ( 図 1 )。

T8 KO/KD

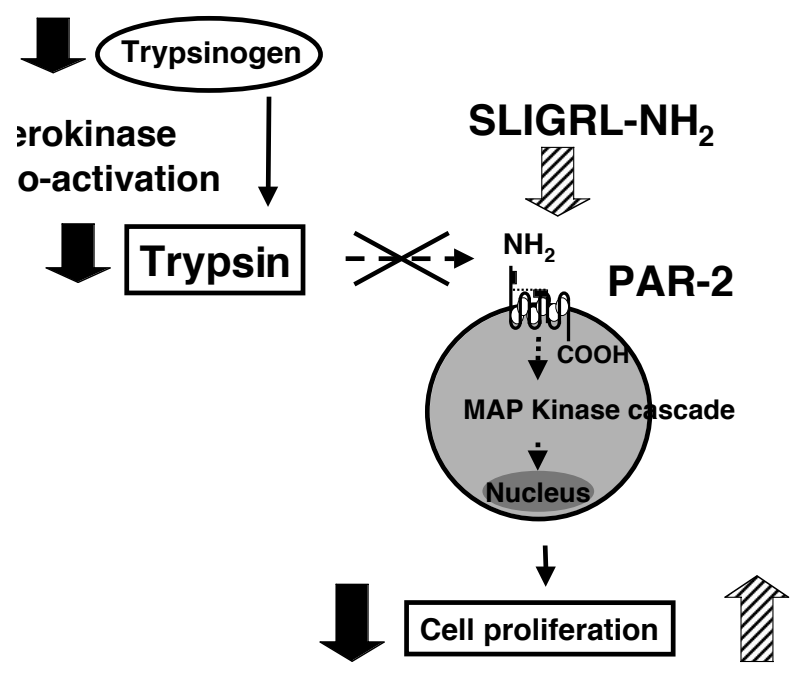

Fig.1. The relationship between trypsin (trypsinogen) and the regulation of PAR-2. Fut 8 knockdown decrease the expression of trypsinogens resulting in the attenuation of TGF- $\beta$ signaling through PAR2 (Filled arrow). PAR-2 activating peptide (SLIGRL-NH ${ }_{2}$ ) can rescue cell proliferation through TGF- $\beta$ signaling (Hatched arrow). 


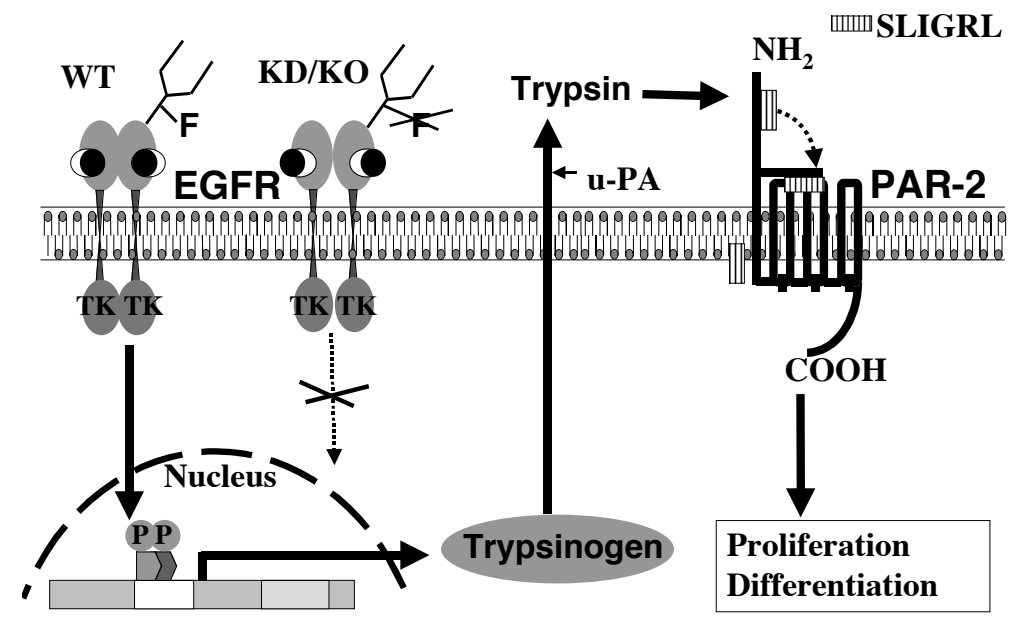

Fig. 2. The relationship between core-fucosylation and the regulation of the EGFR-trypsin-PAR-2 pathway. The loss of $\alpha$ 1,6 core fucose (F) on the extracellular domain of EGFR affects cell proliferation by modulating EGFR phosphorylation. The low levels of EGFR signaling in $F u t 8^{-/-}$mice are associated with growth retardation, at least in part, by a reduced trypsinogen expression which, in turn, attenuates the PAR-2-medaited growth signaling pathway. The important finding of our study was that $\alpha 1,6$ core fucose on the extracellular domain of EGFR has an effect on cell proliferation through the regulation of EGFR-trypsin-PAR-2 signaling.

Moreover, epidermal growth factor (EGF) receptor phosphorylation was attenuated in TGP49-Fut8-KDs, which was highly associated with a reduction of trypsinogens mRNA levels. The addition of exogenous EGF recovered c-fos, c-jun and trypsinogen mRNA expression in TGP49-Fut8-KDs. Again, the EGF induced up-regulation of $\mathrm{c}$-fos and c-jun mRNA expression was significantly blocked by the protein kinase $\mathrm{C}$ (PKC) inhibitor. Our findings clearly demonstrate a relationship between Fut8 and the regulation of EGFRtrypsin-PAR-2 pathway in controlling cell growth, and that the EGFR-trypsin-PAR-2 pathway is suppressed in TGP49-Fut8KDs as well as in $\mathrm{Futb}^{-/}$mice (Fig. 2).

\section{F. Fut8 and B Cell Development (21)}

Mice with a targeted gene disruption of the Fut8 $\left(\mathrm{Futs}^{-/-}\right)$ showed an abnormality in the pro-B to pre-B transition, reduced pre-B cell proliferative responses and a decreased immunoglobulin production. To determine whether the core fucosylated $N$-glycans of ST2 cells (stromal cells) functionally compromised pre-B cell colony formation, we cultivated $\mathrm{Fut}^{+/+}$BM (bone marrow) cells on ST2 cells and on ST2KD cells. The frequency of B cell progenitors was $1 / 251$ on ST2-KD cells, which was less than half of that on ST2 cells (1/114). These results indicate that Fut8 in BM stromal cells is involved in pre-B supporting ability. To ascertain the role of the core fucose of VCAM-1, we compared the binding ability of $\mathrm{Fut}^{+/+}$pre-B cells to ST2 and ST2-KD cells. The core fucosylated $\mathrm{N}$-glycans of VCAM-1 was abolished in ST2KD cells, without any effect on total VCAM-1 expression levels. The $\mathrm{Fut}^{+/+}$pre-B cells showed a weaker adhesion to ST2-KD, indicating that Fut8 in stroma has a positive role in
さらに、TGP49-Fut8-KD 細胞におけるトリプシンの発現 低下は、上皮細胞増殖因子 $(\mathrm{EGF})$ 受容体のリン酸化の抑制と関 倸があることが分かった。よって、低下していたTGP49-Fut8KD 細胞の c-fos、c-jun およびトリプシノーゲンの mRNA の 発現は、EGF の添加によって回復させることができた。この c-fos およびc-jun の mRNA の発現回復は (EGF 経路の下流に ある)プロテインキナーゼCの阻害片によってほぼ完全に遮 断された。我々のこれらの実験結果は、Fut8 と EGFR-trypsinPAR-2 経路は細胞増殖を制御しているということを明確に示 すことが出来たと考えている。さらに、TGP49-Fut8-KD 細胞 に扔ける EGFR-trypsin-PAR-2 経路の抑制は、Fut8 ノックア ウトマウスと同様であった。(図 2 )。

\section{F. Fut8 と B 細胞の初期分化過程 (21)}

Fut8ノックアウトマウスのB Bンパ球の分析によって、 プロ B 細胞からプレ B 細胞への移行に異常があり、プレ B 細 胞の増殖反応が低下しおり、抗体生産量も低下していること が分かった。ST2 細胞 (株化されたストローマ細胞)のコアフ コース化された $N$-結合糖鎖が、プレ B 細胞のコロニー形成 における機能的な障害を起こさせているのかどうか調べるた めに、野生型マウスの BM( 骨髄細胞) をオリジナルの ST2 細 胞拉よび Fut8 をノックダウンした ST2 細胞 (ST2-KD 細胞) の 上で培養した。 B 細胞の前駆細胞コロニー数は、ST2 細胞の 1/114に対してST2-KD 細胞の上では、半分以下の $1 / 251$ であっ た。この結果は、BM 中のストローマ細胞の Fut8 がプレ B 細 胞の支持活性に媣く関与していることを示している。ストロー マ細胞に扔けるVCAM-1 のコアフコースの役目を解明するた めに、野生型マウスのプレ B 細胞と ST2 細胞またはST2-KD 細胞との結合能を比べてみた。ST2-KD 細胞では、VCAM-1 の発現量はST2 細胞のそれと変わらないが、VCAM-1にコア フコース化された $N$-結合糖鎖が殆ど存在しない。野生型マ 
A

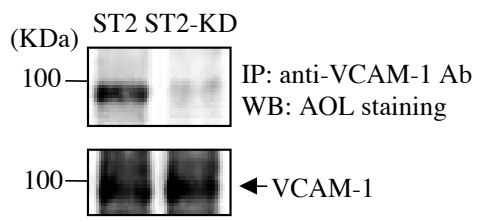

$\mathrm{C}$

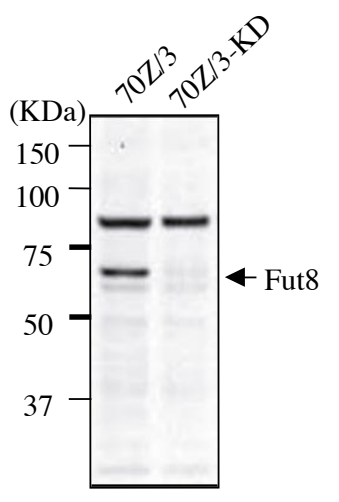

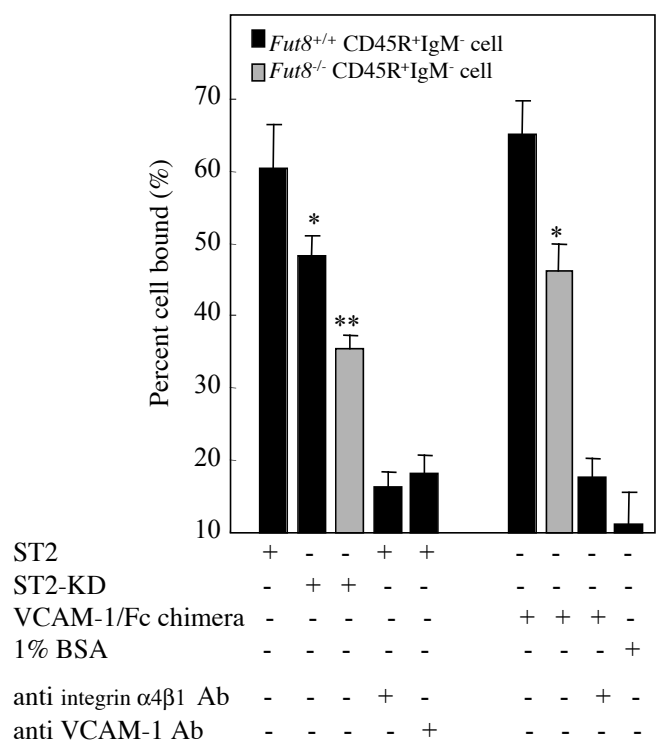

$\mathrm{D}$

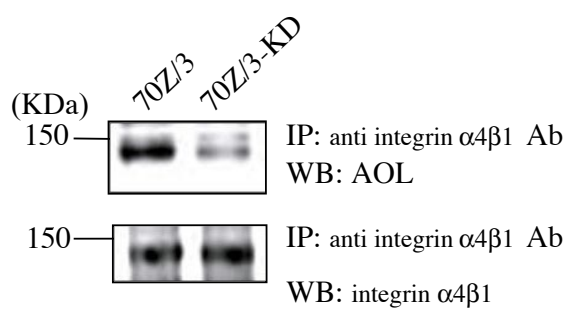

$\mathrm{E}$

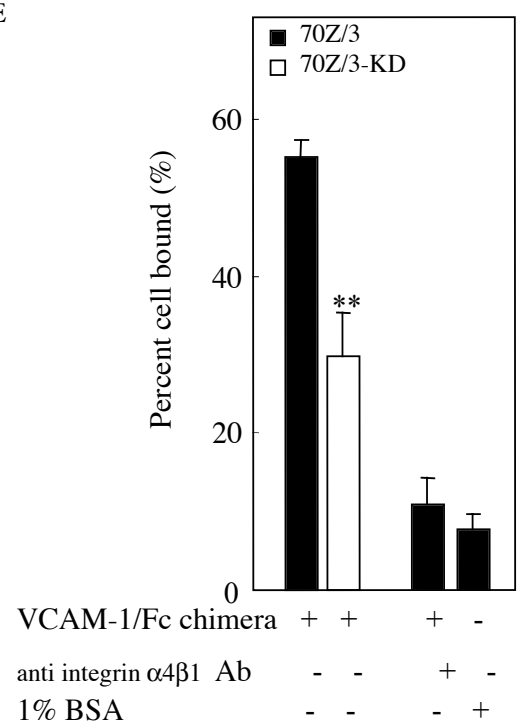

Fig. 3. Loss of core fucose on VCAM-1 and $\alpha 4 \beta 1$ integrin led to a low binding ability of pre-B cells to ST2 and VCAM-1 molecules. A, Reduction in the core fucose of VCAM-1 in ST2-KD was detected by AOL staining. An antibody to VCAM-1 was used in the immunoprecipitation and the immunoprecipitates were resolved by SDS-PAGE on a $7.5 \%$ gel, transferred to a PVDF membrane and probed with the AOL and anti-VCAM-1. The immunoprecipitates were treated with Laemmli sample buffer containing 2-ME; B, Inhibition of binding of $\mathrm{CD}_{45 \mathrm{R}^{+} \mathrm{IgM}}^{-}$cells to ST2 and VCAM-1 molecules as the result of de-core fucosylation. Quantification of cell numbers attached to the plates was carried out by means of fluorescence microassay. CD45R ${ }^{+} \mathrm{IgM}^{-}$cells were GFSE labeled and used in the cell adhesion assay as described in Materials and Methods; C, Expression of Fut8 on 70Z/3 derivative cells. Ten $\mu \mathrm{g}$ of cell lysates from 70Z/3 and 70Z/3-KD cells were subjected to a western blot analysis using $15 \mathrm{C} 6$ antibody; D, Reduction in core fucose of $\alpha 4 \beta 1$ integrin in $70 \mathrm{Z} / 3-\mathrm{KD}$ was detected by AOL staining. The surfaces of $70 \mathrm{Z} / 3$ and $70 \mathrm{Z} / 3-\mathrm{KD}$ cells were biotinylated, and whole cell lysates were immunoprecipitated with an anti- $\alpha 4 \beta 1$ integrin antibody. The immunoprecipitates were treated with Laemmli sample buffer without 2-ME; E, Comparison of the binding ability of $70 \mathrm{Z} / 3$ and 70Z/3-KD cells to VCAM-1 molecules. The binding ability of pre-B cells was evaluated by counting the number of B cells bound per well. Monoclonal antibodies $(10 \mu \mathrm{g} / \mathrm{ml})$ to $\alpha 4 \beta 1$ integrin and VCAM-1 were added as indicated. Adherence is expressed as a percentage. Each value represents the mean \pm SD of three experiments. 
tethering pre-B cells. On the other hand, $F u t 8^{-/-}$pre-B cells showed weaker binding to ST2-KD than $F u t 8^{+/+}$pre-B cells. Furthermore, when the recombinant mouse VCAM-1/Fc chimera was used, binding of $\mathrm{Fut}^{-/}$pre-B cells was weaker than that of $F u t 8^{+/+}$pre-B cells, suggesting that the adhesion of pre-B cells themselves by integrin $\alpha 4 \beta 1$ was also impaired by defect of Fut8 in pre-B cells (Fig. 3).

To further examine the importance of the core fucosylated $N$-glycans on integrin $\alpha 4 \beta 1$, we stably silenced Fut 8 expression in a pre-B cell line, 70Z/3 cells, and named 70Z/3-KD. Fut 8 expression and the core fucosylated $\mathrm{N}$-glycans of integrin $\alpha 4 \beta 1$ were ablated in $70 Z / 3-K D$. In a binding assay, 70Z/3-KD cells showed an impaired adhesion to VCAM-1, compared to mock cells. Preincubation of $70 \mathrm{Z} / 3$ cells with an anti-integrin $\alpha 4 \beta 1$ antibody significantly blocks the binding of $70 \mathrm{Z} / 3$ to VCAM-1. Collectively, these results demonstrated that core fucosylation plays a pivotal role in a key event in pre-B cell development; integrin $\alpha 4 \beta 1$ /VCAM1-mediated interactions between pre-B cells and stromal cells (Fig 4).

\section{G. Concluding Remarks}

In the coming years, advances in molecular biology and molecular technologies for not only proteomics but also glycomics are likely to have a profound impact on diagnostic pathology. It is well known that large numbers of proteins undergo post-translational modifications with corresponding changes in their structures and functions. Among the various post-translational modification reactions of proteins, glycosylation is the most abundant. However, only glycomics approach does not provide any functional meaning of the glycoproteins as we have lessened already from proteomics
ウスのプレ B 細胞は ST2-KD 細胞に弱くしか結合しない。こ のことは、ストローマ細胞の Fut8がプレ B 細胞を繋ぎとめて おくのに役に立っているということを示している。一方、Fut8 ノックアウトマウスのプレ B 細胞は、野生型マウスのプレ B 細胞に比べて ST2-KD 細胞への結合は弱い。さらに、組換え 体マウス VCAM - 1/Fc キメラタンパク質と Fut8 ノックアウ トマウスのプレ B 細胞の結合は、野生型マウスのプレ B 細胞 との結合に比べて弱い。つまり、ストローマ細胞との接着に はプレ B 細胞の $\alpha 4 \beta 1$ インテグリンが関与しているが、Fut8 ノックアウトマウスのプレ B 細胞は充分にその機能を果たさ ないわけである(図 3)。

そこで、 $\alpha 4 \beta 1$ インテグリンのコアフコース化された N 結合糖鎖の重要性を調べるために、定常的にFut8 の発現を ノックダウンしたプレ B 細胞 (70Z/3-KD 細胞) を作成した。 70Z/3-KD 細胞に打いては、予想通り Fut8 の発現とコアフコー ス化された $N$-結合糖鎖を持つ $\alpha 4 \beta 1$ インテグリンの発現が、 抑制されていた。70Z/3-KD 細胞の VCAM-1 に対する結合は、 $70 Z / 3$ の mock 細胞に比べて弱い。70Z/3 細胞と抗 $\alpha 4 \beta 1$ イン テグリン抗体を予め混合した場合、VCAM-1 に対する結合は殆 どブロックされた。

以上の実験結果から、 $N$-結合糖鎖のコアフコース化はプ レB 細胞の $\alpha 4 \beta 1$ インテグリンとストローマ細胞の VCAM - 1 双方に挍いて必須であり、その相互作用はプレ B 細胞の分化 増殖にきわめて重要であると証明できた ( 図 4)。

\section{G. 結 語}

これからの数年間のプロテオミクスのみならずグライコ ミクス研究のための分子生物学抒よび分子工学の発展は、診 断病理学の分野に対して非常に大きな影響を与えるであろう。 本文でも述べてきたように、非常に多くのタンパク質が翻訳 後修飾を受けており、そのことによって構造や機能に変化が 生まれている。その中でも最も一般的なのが、糖鎖修飾である。

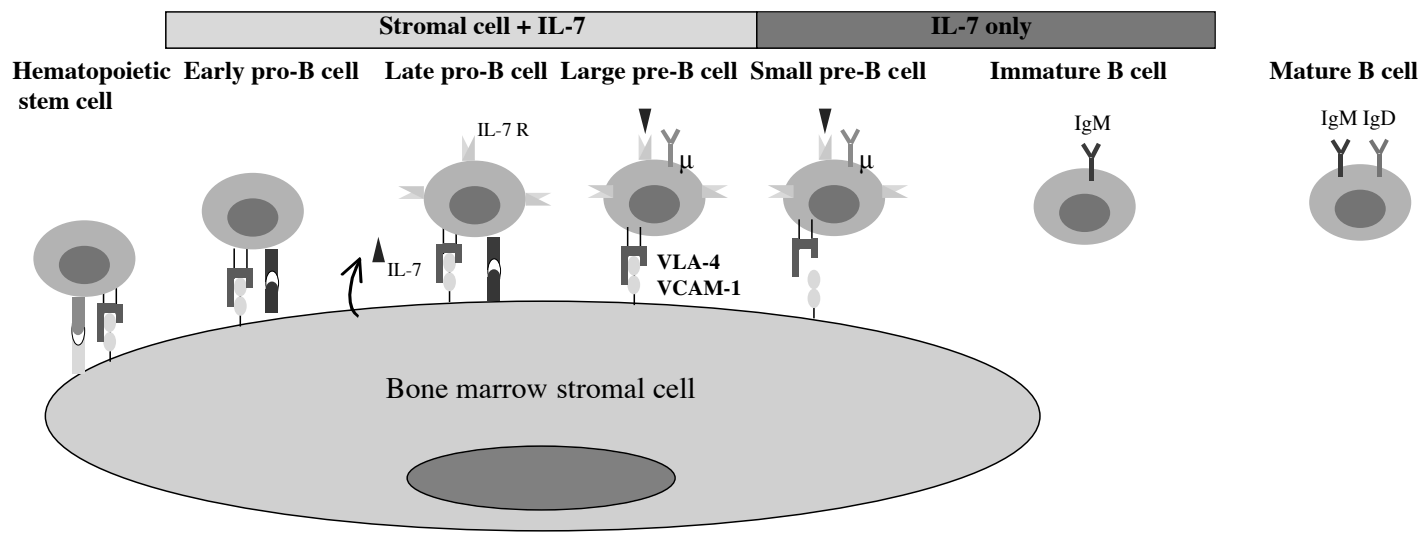

Fig. 4. Simplified differentiation diagram for development of $\mathbf{B}$ cells. Alpha 1,6-fucosyltransferase (Fut8) is responsible for the alpha 1,6 core fucosylation of $N$-glycans, which could modify the functions of glycoproteins. The loss of a core fucose in both very late antigen 4 (VLA-4, integrin $\alpha 4 \beta 1$ ) and vascular cell adhesion molecule 1 (VCAM-1) led to a decreased binding between pre-B cells and stromal cells, which impaired pre-B cells generation in $\mathrm{Futs}^{-/}$mice. 
approach which does not give any functional meaning unless functional proteomics have been carried out.

In the functional glycomics methodology presented in this review, we used gene targeting mice and knockdown cells of Fut8 as a model. As described above, the structural modulation of glycans by Fut 8 could significantly alter a variety of biological functions including cell proliferation and signal transduction.

A strategy for identifying proteins targeted by a glycosyltransferase is not an easy task. Target molecules seem to be different for each glycosyltransferase. The polyacrylamide gel electrophoresis (including twodimensional polyacrylamide gel electrophoresis; 2-D PAGE) followed by a lectin blot described in this review is one of the currently available glyco-proteomic and proteo-glycomic approaches to search for the target molecules. The introduction of a glycosyltransferase gene into specific cells and tissues may open up approaches to the study of glycomics and may lead to functional genomic studies in the post-genome era of research.

\section{Acknowledgements}

The author thanks Drs Wenzhe Li, Takatoshi Nakagawa, Katsuhiko Ishihara, Takafumi Yokota, Miyako Nakano, Hideyuki Ihara, Nobuto Koyama, Mutsumi Sano, Ikunoshin Kato, Jianguo Gu, Koichi Honke, Eiji Miyoshi, and Naoyuki Taniguchi for collaboration and special support. And the author has to thank Mses Eriko Sasabe, Mami Nishikawa, and Key Mikami for excellent assistance. The works of Fut8 study were partly supported by the Core Research for Evolutional Science and Technology (CREST) program of Japan Science and Technology Agency, and the 21st Century Center of Excellence (COE) program from the Ministry of Education, Culture, Sports, Science, and Technology of Japan, and Core to Core program (JSPS).
しかしながら、機能的プロテオミクス解析というものが行わ れてきているが、糖鎖機能解析としては充分ではない。

本総説では、我々の行ってきているFut8 の遺伝子ターゲッ ティングマウスやノックダウン細胞を用いた解析をモデルに 糖鎖機能解析法の紹介を抗こなった。本稿で述べてきたよう に、Fut8 による糖鎖修飾は細胞増殖や情報伝達を含めた生物 学的機能を変化させるということが糖鎖機能解析によって判 明したのである。

糖転移酵素のターゲットタンパク質を同定する戦略は、そ う簡単ではない。この場合のターゲット分子は、それぞれの 糖転移酵素で異なっている。PAGE(2-D PAGE も含めて)につ いでレクチンブロットを行うという本総説でも紹介した方法 は、ターゲット分子を探すのに良い方法である。そして今後、 糖転移酵素を特異的な細胞や臟器に導入し研究することは、 グライコミクス研究の門戸を広く開けることができ、ポス卜 ゲノム研究分野に扔いて機能的糖鎖解析研究を先導すること ができるであろう。

\section{謝 辞}

著者は、共同研究および特別なご高配を賜りました李文 哲、中川孝俊、石原克彦、横田貴史、中の三弥子、井原秀之、 小山信人、佐野睦、加藤郁之進、顧建国、本家孝一、三善英知、 谷口直之の各博士に深謝いたします。また、篠部衣利子、西 川真美、三神恵の素晴らしいサポートに感謝いたします。こ こに紹介したFut8 の研究は、CREST、COE、JSPS の各プロジェ クトのグラントの支援のもとで行われました。

\section{References}

1. Varki, A. (1993) Glycobiology 3, 97-130

2. Isaji, T., Gu, J., Nishiuchi, R., Zhao, Y., Takahashi, M., Miyoshi, E., Honke, K., Sekiguchi, K., and Taniguchi, N. (2004) J. Biol. Chem. 279, 19747-19754

3. Stanley, P. (2002) Biochim. Biophys. Acta 157, 363-368

4. Hakomori, S. (1989) Adv. Cancer Res. 52, 257-331

5. Taniguchi, N., Ekuni, A., Ko, J. H., Miyoshi, E., Ikeda, Y., Ihara, Y., Nishikawa, A., Honke, K., and Takahashi, M. (2001) Proteomics 1, $239-247$

6. Taniguchi, N. (2006) IUBMB Life 58, 269-272

7. Voynow, J., Kaiser, R., Scanlin, T., and Glick, M. (1991) J. Biol. Chem. 266, 21572-21577

8. Uozumi, N., Yanagidani, S., Miyoshi, E., Ihara, Y., Sakuma, T., Gao, C., Teshima, T., Fujii, S., Shiba, T., and Taniguchi, N. (1996) J. Biol. Chem. 271, 27810-27817

9. Yanagidani, S., N., U., Ihara, Y., Miyoshi, E., Yamaguchi, N., and Taniguchi, N. (1997) J. Biochem. (Tokyo) 121, 626-632

10. Kaminska, J., Glick, M., and Koscielak, J. (1998) Glycoconj. J. 15, 783-788

11. Breton, C., Oriol, R., and Imberty, A. (1998) Glycobiology 8, 87-94

12. Miyoshi, E., Uozumi, N., Noda, K., Hayashi, N., Hori, M., and Taniguchi, N. (1997) Int. J. Cancer 72, 1117-1121

13. Toyoshima, S., Osawa, T., and Tonomura, A. (1970) Biochim. Biophys. Acta 221, 514-521

14. Block, T., Comunale, M., Lowman, M., Steel, L., Romano, P., Fimmel, C., Tennant, B., London, W., Evans, A., Blumberg, B., Dwek, R., Mattu, T., and Mehta, A. (2005) Proc. Natl. Acad. Sci. USA 102, 779-784 
15. Aoyagi, Y., Suzuki, Y., Igarashi, K., Saitoh, A., Oguro, M., Yokota, T., Mori, S., Suda, T., Isemura, M., and Asakura, H. (1993) Br. J. Cancer 67, 486-492

16. Abelev, G. I., Perova, S. D., Khramkova, N. I., Postnikova, Z. A., and Irlin, I. S. (1963) Transplantation 1, 174-180

17. Deutsch, H. (1991) Adv. Cancer Res. 56, 253-312

18. Nishi, S. (1970) Cancer. Res 30, 2507-2513

19. Wang, X., Inoue, S., Gu, J., Miyoshi, E., Noda, K., Li, W., Mizuno-Horikawa, Y., Nakano, M., Asahi, M., Takahashi, M., Uozumi, N., Ihara, S., Lee, S. H., Ikeda, Y., Yamaguchi, Y., Aze, Y., Tomiyama, Y., Fujii, J., Suzuki, K., Kondo, A., Shapiro, S. D., Lopez-Otin, C., Kuwaki, T., Okabe, M., Honke, K., and Taniguchi, N. (2005) Proc. Natl. Acad. Sci. USA 102, 15791-15796

20. Li, W., Nakagawa, T., Koyama, N., Wang, X., Jin, J., Mizuno-Horikawa, Y., Gu, J., Miyoshi, E., Kato, I., Honke, K., Taniguchi, N., and Kondo, A. (2006) Glycobiology 16, 1007-1019

21. Li, W., Ishihara, K., Yokota, T., Nakagawa, T., Koyama, N., Jin, J., Mizuno-Horikawa, Y., Wang, X., Miyoshi, E., Taniguchi, N., and Kondo, A. (2007) Glycobiology

Received on December 7, 2007, accepted on December 11, 2007

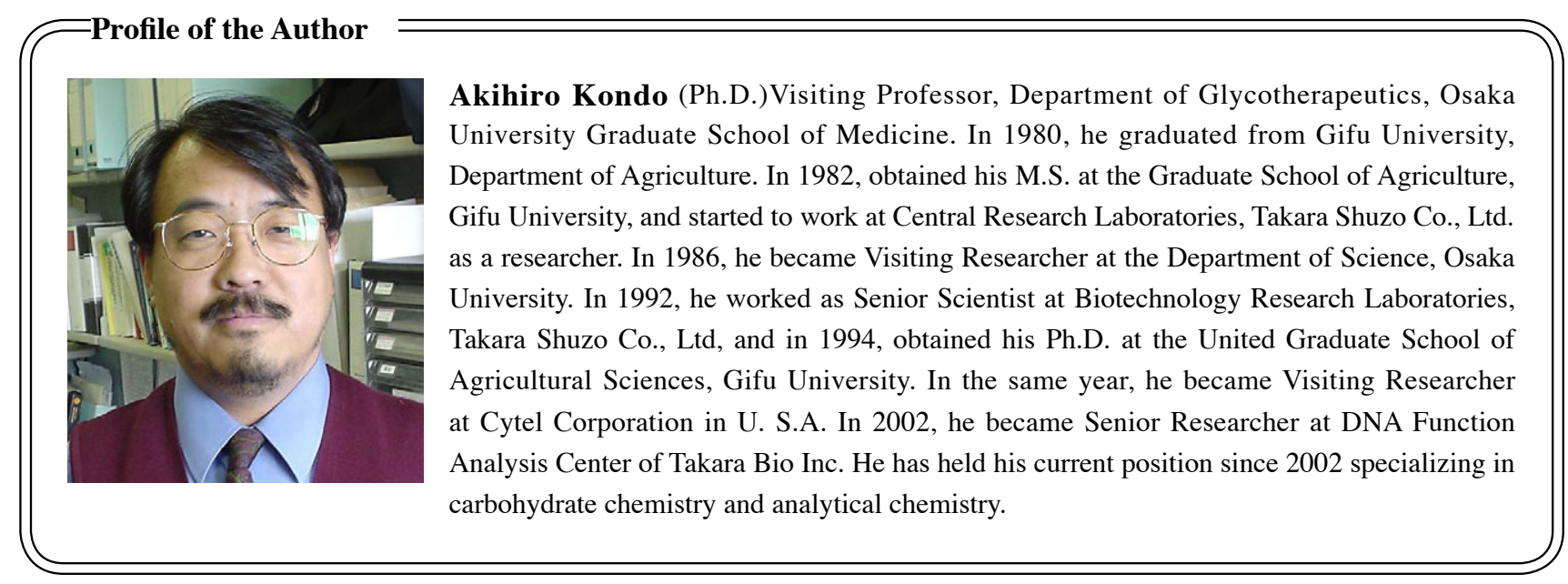

